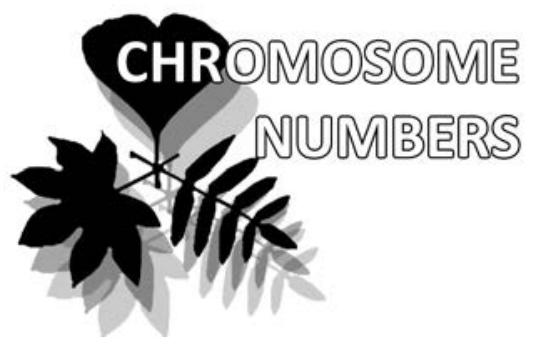

\title{
Chromosome numbers in some vascular plants from the highlands of south-east Altai, Republic of Altai, Russia
}

\author{
Elena A. Korolyuk* \& Tatiana V. An’kova
}

\begin{abstract}
Elena A. Korolyuk*
e-mail:1_koroljuk@ngs.ru

Tatiana V. An’kova

e-mail: ankova_tv@mail.ru
\end{abstract}

Central Siberian Botanical Garden SB RAS, Novosibirsk, Russia

*corresponding author

Manuscript received: 08.02.2019

Review completed: 17.02.2019

Accepted for publication: 22.02.2019

Published online: 23.02.2019

\begin{abstract}
A B S T R A C T
The paper provides the chromosome numbers $(2 n)$ for ten species and one subspecies of vascular plants from the families Asteraceae, Brassicaceae, Caryophyllaceae, Ranunculaceae, and Valerianaceae in highlands of the Kuray Range (South-Eastern Altai). Most of these species are endemic or rare. The species Leiospora excapa (C.A. Mey.) F. Dvorak $(2 n=14)$ was studied for the first time. For Minuartia verna (L.) Hiern. $(2 \mathrm{n}=24)$ and Pulsatilla bungeana C.A. Mey. ex Ledeb. $(2 n=16)$ we give the chromosome numbers first for Siberia; for Erigeron uniflorus L. subsp. eriocalyx (Ledeb.) Á. Löve \& D. Löve $(2 \mathrm{n}=18)$, Packera heterophylla (Fisch.) E. Wiebe $(2 \mathrm{n}=46)$, Pulsatilla turczaninovii Kryl. \& Serg. $(2 \mathrm{n}=16)$ and Valeriana petrophila Bunge $(2 \mathrm{n}=14)$, we give the chromosome numbers for the first time from West Siberia. Crepis chrysantha (Ledeb.) Turcz. $(2 \mathrm{n}=16)$ is a new cytotype for West Siberia. For Dracocephalum imberbe Bunge, we confirm the previously described cytomixis. For each species we give both their distribution areas and previous chromosome number data.
\end{abstract}

Ke ywords: chromosome numbers, vascular plants, endemic species, rare plants, South-Eastern Altai, Kuraiskii Range, Republic of Altai, West Siberia, Russia

\section{P E 3 Ю M E}

Королюк Е.А., Анькова Т.В. Числа хромосом некоторых сосудистых растений из высокогорий Юго-Восточного Алтая, Республика Аیтай, Россия. Приводятся числа хромосом (2n) Аля 10 виАов и 1 подвиАа сосуАистых растений (Asteraceae, Brassicaceae, Caryophyllaceae, Ranunculaceae, Valerianaceae) из труднодоступных высокогорий Курайского хребта (ЮгоВосточный А^тай), большинство виАов эндемичные и редкие. Впервые Аля науки исследован вид Leiospora excapa (C.A. Mey.) F. Dvorak $(2 \mathrm{n}=14)$. Аля виАов Minuartia verna (L.) Hiern. $(2 \mathrm{n}=24)$, Pulsatilla bungeana C.A. Mey. ex Ledeb. $(2 \mathrm{n}=16)$ числа хромосом приводятся впервые Аля Сибири; Erigeron uniflorus $\mathrm{L}$. subsp. eriocalyx (Ledeb.) Á. Löve \& D. Löve $(2 \mathrm{n}=18)$, Packera heterophylla (Fisch.) E. Wiebe $(2 \mathrm{n}=46)$, Pulsatilla turczaninovii Kryl. \& Serg. $(2 \mathrm{n}=16)$ и Valeriana petrophila Bunge $(2 \mathrm{n}=14)$ - впервые Амя Западной Сибири. Crepis chrysantha (Ledeb.) Turcz. $(2 \mathrm{n}=16)$ - новый цитотип Аля Западной Сибири. У Dracocephalum imberbe Bunge подтверждено, описанное ранее явление цитомиксиса. Аیя кажАого вида указан ареал и приведены данные по числам хромосом..

К $\boldsymbol{\Lambda ю ч е в ы е ~ с ~ с л о в а : ~ ч и с л а ~ х р о м о с о м , ~ с о с у д и с т ы е ~ р а с т е н и я , ~ э н д е м и ч н ы е ~}$ виды, редкие растения, Юго-Восточный Алтай, Курайский хребет, Респуб̃лика А^тай, Россия
We studied the chromosome numbers $(2 \mathrm{n})$ on ten species and one subspecies of vascular plants, from the families Asteraceae, Brassicaceae, Caryophyllaceae, Ranunculaceae and Valerianaceae in the Kuraiskii Range, South-Eastern Altai (the Republic of Altai). We collected the seeds and herbarium material in situ. The chromosome numbers were determined according to the standard approach: the karyological analysis is made on root meristem squash preparations from seedlings. Seeds are sprouted in Petri dishes on wet sterile sand at $27^{\circ} \mathrm{C}$ and light regime providing 16 hours of daylight and eight hours of darkness. The germs are treated in $0.2 \%$ colchicine for two hours and then fixed in a mixture of ethanolacetic acid (3:1). The chromosomes are stained with acetohaematoxyline according to Smirnov (1968). Slides were examined under Axioscop-40 microscope. We conducted the chromosome analyses on 5-10 slides under 100× magnification. The herbarium samples are stored at the Herbarium of the Central Siberian Botanical Garden SB RAS (NS).

We collected the samples from three ecotopes at the same geographical location: Republic of Altai, Ulaganskii Raion, $9 \mathrm{~km}$ east of Aktash settlement, the Kuraiskii Range, $50^{\circ} 19^{\prime}$ N, 87²4'E. 2613 m alt., 25 Jul 2017. Coll. A.Yu. Korolyuk, E.A. Korolyuk. (NS).

After description of the general geographic distribution ("distribution") of each species, we provide a herbarium sample's label with the number of ecotope: 1 - herb tundra, $\mathbf{2}$ - the roadside and $\mathbf{3}$ - tundra on rock debris. The number of the sample is given for each case (e.g. 1: no. 159): 


\section{ASTERACEAE \\ Aster alpinus L., 2n=36 (Fig. 1A)}

Distribution: Eurasia, West America. Boreal-montane. 1: no. 519. The species was studied from different parts of its distribution range, there are records of chromosome numbers 2n=18, 27, 36 (Goldblatt \& Johnson 1979+, Agapova et al. 1990, Rice et al. 2015). The previous record from Altai was 2 n=18 (Krogulevich \& Rostovtseva 1984, Krasnikov 1985), while our data confirm the previously stated $2 n=36$ in alpine populations of Altai (Sokolovskaya \& Strelkova 1938, 1948; Krogulevich \& Rostovtseva 1984). Tetraploid $(4 \mathrm{x}), \mathrm{x}=9$. Variable ploidy.

\section{Crepis chrysantha (Ledeb.) Turcz., 2n=16 (Fig. 1B)}

Distribution: East Europe, Asia. Mountain tundras. 1: no. 549. Polymorphic species. There was only one record $2 \mathrm{n}=8$ in Altai population from the Seminskii Range (Pulkina 1988), and there are also diploid records $(2 \mathrm{n}=8)$ for North Urals, East Kazakhstan, East Siberia, Chukotka and the Far East (Goldblatt \& Johnson 1979+, Agapova et al. 1990, Rice et al. 2015+). In West Sayan populations S.V. Pulkina (1988) revealed $2 \mathrm{n}=8+1 \mathrm{~B}$.

On the samples from West Sayan, Tyva and Chukot$\mathrm{ka}$ the tetraploids $(2 \mathrm{n}=16)$ have been found (Krogulevich 1978, Zhukova 1980, 1982, Krogulevich \& Rostovtseva 1984). The sample of Crepis hokkaidoensis Babc. from Sakhalin Island re-identified later by N.S. Probatova et al. (2007) as $C$. chrysantha, was also tetraploid. We found tetraploid cytotype of $C$. chrysantha which is new for West Siberia. Tetraploid $(4 \mathrm{x}), \mathrm{x}=4$. Variable ploidy.

\section{Crepis multicaulis Ledeb., $2 \mathrm{n}=10$ (Fig. 1C)}

Distribution: Europe, Middle and Central Asia. Montane. 1: no. 546. In Altai, 2n=10 was found on populations from the Kozhalyu (Krasnikov 1985) and Yuzhno-Chuiskii (Pulkina 1988) ranges. The same chromosome number was reported by Krogulevich \& Rostovtseva (1984) from Tyva, West Sayan. The samples from Scandinavia and Tadjikistan showed the same chromosome number as well (Goldblatt \& Johnson 1979+, Astanova 1989, Rice et al. 2015+). Diploid $(2 \mathrm{x}), \mathrm{x}=5$.

Erigeron uniflorus L. subsp. eriocalyx (Ledeb.) Á. Löve \& D. Löve (Erigeron eriocalyx (Ledeb.) Vierh.), 2n=18 (Fig. 2A)

Distribution: the subspecies is common in the alpine regions of Europe, Siberian and Mongolian highlands. Tundras and alpine belts of the mountains. 1: no. 516. For Asian part of the distribution range, the diploid chromosome number $(2 \mathrm{n}=18)$ Krogulevich \& Rostovtseva (1984), as well as Chepinoga (2014) reported only for East Siberia. In West Siberia, we give the data on chromosome number data for the first time. Diploid (2x), $x=9$.

Packera heterophylla (Fisch.) E. Wiebe (Tephroseris heterophylla (Fisch.) Konechn., Senecio resedifolius Less.), 2n=46

Distribution: Holarctic. Arctic-alpine. 1: no. 550. For Asian part of the distribution area (West and East Sayan, the Putorana Plateau, Yakutia, and Chukotka Upland), the chromosome numbers are reported: $2 \mathrm{n}=28,46,80,90,92$, 114, 138 (Krogulevich \& Rostovtseva 1984). We obtained first chromosome number data from West Siberia. It is, most probably, aneuploid. Variable ploidy.

\section{BRASSICACEAE}

Leiospora excapa (C.A. Mey.) F. Dvorak (Parrya excapa C.A. Mey.), $2 \mathrm{n}=14$ (Figs 1D, 2B)

Distribution: Alpine species, with a narrow distribution area in the Republic of Altai, Tyva and Mongolia (Rybinskaya 1994), 2: no. 488. We determined the chromosome number in this species for the first time. Diploid (2x), $x=7$.

\section{CARYOPHYLLACEAE}

Minuartia verna (L.) Hiern. (Arenaria verna L.), $2 \mathrm{n}=24$

Distribution: Europe, the Caucasus, Middle Asia, Siberia, Mongolia, and the Far East. Widely distributed species. 1: no. 545. There are records of chromosome number $2 \mathrm{n}=24,26$, $48,78,120$ for this species in populations from Europe, the Caucasus, and the Far East (Goldblatt \& Johnson 1979+, Rice et al. 2015). We give the first data on chromosome number for Siberia. Diploid (2x), $\mathrm{x}=12$. Variable ploidy.

\section{LAMIACEAE}

\section{Dracocephalum imberbe Bunge, 2n=14 (Figs 1E, 2C)}

Distribution: alpine belt of the mountains of South Siberia, Middle Asia, West Mongolia and North-East China. Described from Altai. 3: no. 515. There are three closely related species growing in Altai: Dracocephalum grandiflorum L., $D$. altaense Laxm. and D. imberbe Bunge. The only chromosome number known for the first two species is $2 n=14$ (Sokolovskaya \& Strelkova 1938). Besides, some authors combine these species in D. grandiflorum L. (Peshkova 1997), while $D$. imberbe has clearly distinguished morphological characteristics and different chromosome numbers reported in literature: $2 \mathrm{n}=10$ (Sokolovskaya \& Strelkova 1938, 1948) and $n=7$ (Krasnoborov et al. 1980) from Altai, but $2 n=14$ (Budantzev 1986) from Kyrgyzstan.

Rostovtseva (1978) recorded the cytomixis phenomenon in the plants of $D$. imberbe collected from the Kuraiskii Range (Ulaganskii Raion, the Republic of Altai), though the haploid chromosome number from flower buds could not be determined. Later, Krasnoborov et al. (1980) published the data from two populations of close geographic regions of the Republic of Altai: approximately $n=7$ for Ulaganskii Raion (probably, from the same samples as Rostovtseva examined) and $\mathrm{n}=7$ for Kosh-Agachskii Raion.

There are samples of $D$. imberbe Bunge stored at Krasnoborov Herbarium, which Rostovtseva (1978) cites in her paper on cytomixis though without mentioning the determined chromosome number. This Herbarium contains another sample (Altai, Kosh-Agachskii Raion, western slope of the Kozholyu Range in the valley of the left tributary of the Buguzun River, 2800 m a.s.l., pebble-ped, 14.08.1981) with remark made by A.A. Krasnikov on determined chromosome number $2 \mathrm{n}=14$ (Krasnikov, unpublished data).

In course of examination of 30 root samples, we noticed that in all preparations containing both mitotic plates and cells with easily discerned chromosome number $2 n=14$ there are rather common cells with the chromosome number ranging from 8 to 20 (Fig. 1F).

Thus, our data redouble previous ones for the samples from Ulaganskii Raion (the Kuraiskii Range) and confirm the phenomenon of mixoploidy in this species. 

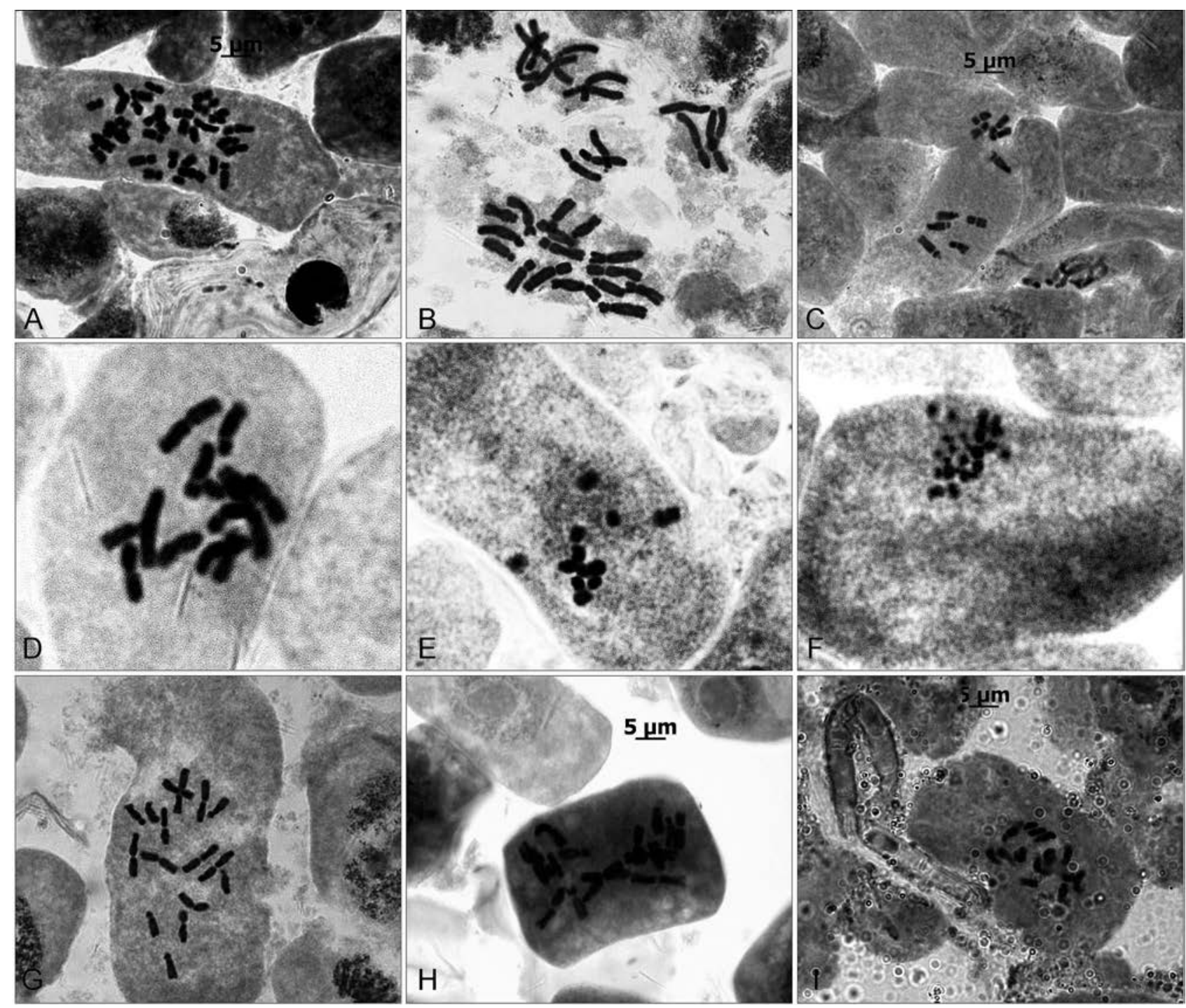

Figure 1 Mitotic metaphases: A - Aster alpinus, 2n=36; B - Crepis chrysantha, 2n=16; C - Crepis multicaulis, 2n=10; D - Leiospora excapa, 2n=14; $\mathrm{E}-$ Dracocephalum imberbe, $2 \mathrm{n}=14 ; \mathrm{F}-$ Dracocephalum imberbe, $2 \mathrm{n} \approx 20 ; \mathrm{G}-$ Pulsatilla bungeana, $2 \mathrm{n}=16 ; \mathrm{H}-$ Pulsatilla turczaninovii, $2 \mathrm{n}=16$, $\mathrm{I}-$ Valeriana petrophila, $2 \mathrm{n}=14$. Scale bar $-5 \mu \mathrm{m}$

\section{RANUNCULACEAE}

\section{Pulsatilla bungeana C.A. Mey. ex Ledeb., $2 \mathrm{n}=16$} (Figs 1G, 2D)

Distribution: endemic of South Siberia and Mongolia (Timokhina 1993), 1: no. 518. On mountains. The European authors (Uellner 1954, Baumberg 1970) state the chromosome number for this species to be $2 \mathrm{n}=16$ and 32 . Besides determining the chromosome number in his summarizing paper, Baumberg provided the karyogram and a high-quality photo of the plate. Unfortunately, the origin of the sample is from horticulture (Erlenbach, Switzerland) and the Botanical Garden of Geneva. Thus, we consider our data on chromosome number to be the first for Siberia. Diploid (2x) $\mathrm{x}=8$. Variable ploidy.

\section{Pulsatilla turczaninovii Kryl. \& Serg., 2n= 16 (Fig. 1H)}

Distribution: widely distributed in Asia. Steppe meadows, pine forests edge, on sands. 1: no. 487. The chromosome number that we state coincides with the records from Tyva, Mongolia and the Far East (Fedorov 1969, Krogulevich \&
Rostovtseva 1984; Volkova \& Ulanova 1986, Probatova et al. 2004). The chromosome number is the first for West Siberia. Diploid $(2 \mathrm{x}), \mathrm{x}=8$.

\section{VALERIANACEAE}

Valeriana petrophila Bunge, 2n=14 (Figs 1I, 2E)

Distribution: alpine belts in the mountains of Altai, Tyva, South Buryatia, and North Mongolia (Kurbatski 1996), 3: no. 552. The only obtained chromosome number for this species was from Tyva, Mongun-Taiga (Krasnikova et al. 1983): $2 \mathrm{n}=14$. We determined the chromosome number first for West Siberia. Diploid (2x), $\mathrm{x}=7$.

\section{CONCLUSION}

A gap still exists in cytological data from the alpine flora of Altai. According to recent studies (Krasnoborov \& Artemov 2012), the flora of South-East Altai consists of 1365 species. Based on the analysis of caryological data for Altai species and our provisional estimations, we came to the point 

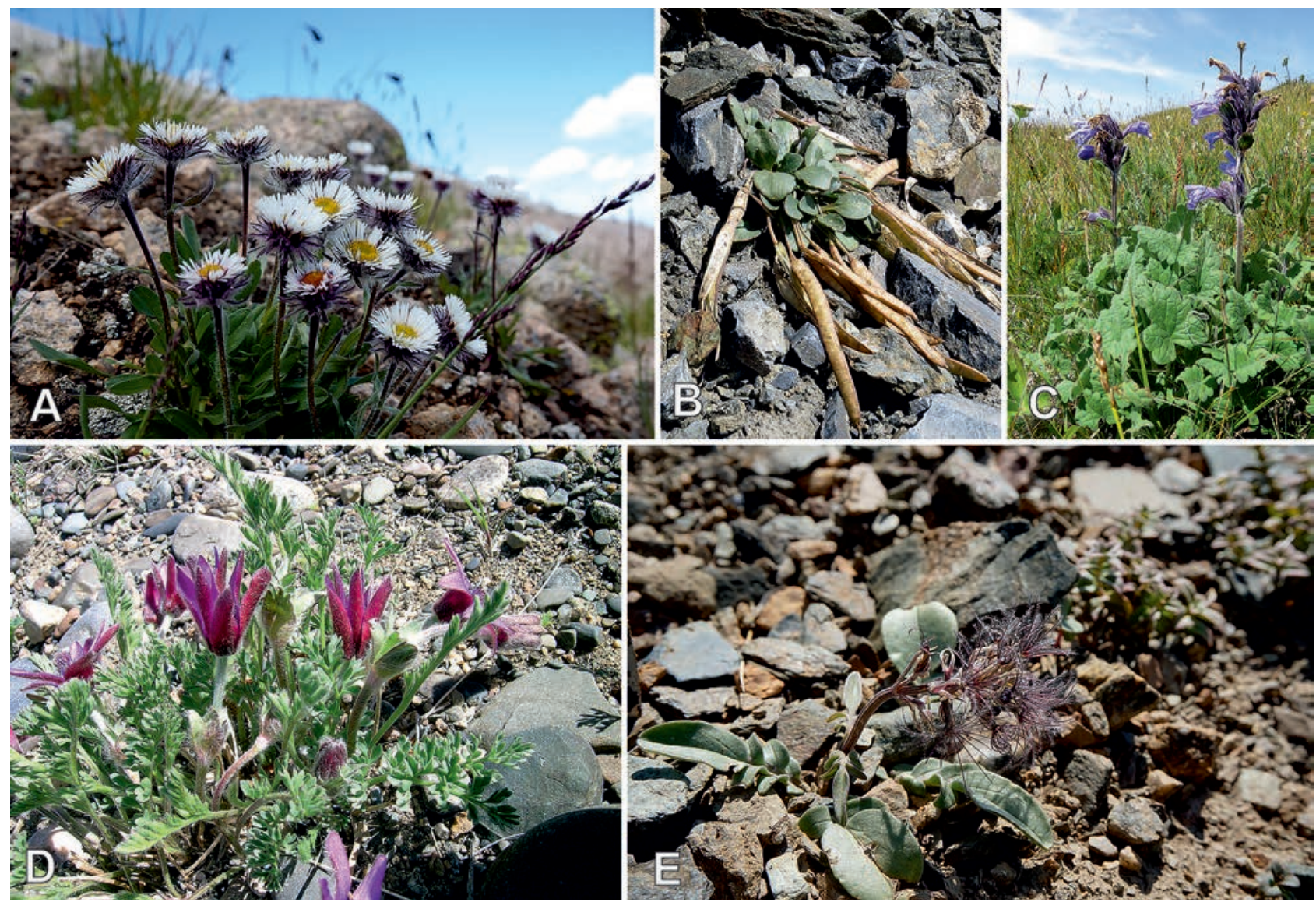

Figure 1 Endemic species on the Kuray Range: A - Erigeron uniflorus subsp. eriocalyx; B - Leiospora excapa; C - Dracocephalum imberbe; D Pulsatilla bungeana; $\mathrm{E}$ - Valeriana petropbila

that only about $10 \%$ of South-East Altai flora has been studied. First of all, this is due to the difficulties in sampling in remote areas. From 11 taxa of vascular plants from SouthEast Altai, we determined the chromosome number of Leiospora excapa $(2 \mathrm{n}=14)$ for the first time. For Minuartia verna $(2 n=24)$ and Pulsatilla bungeana $(2 n=16)$ the chromosome numbers are stated for the first time for Siberia. For Erigeron uniflorus subsp. eriocalyx $(2 \mathrm{n}=18)$, Packera heterophylla $(2 \mathrm{n}=46)$, Pulsatilla turczaninovii $(2 \mathrm{n}=16)$, and Valeriana petrophila $(2 \mathrm{n}=14)$ we discovered the chromosome number for the first time for West Siberia. Crepis chrysantha $(2 \mathrm{n}=16)$ is a new cytotype for West Siberia. Among studied taxa, we revealed 5 diploid species, 4 species with variable ploidy $(2 \mathrm{x}, 4 \mathrm{x})$, as well as one aneuploid and one mixoploid species.

\section{ACKNOWLEDGEMENTS}

The authors are grateful to A.Yu. Korolyuk for help in determination of the species and their photos. The study was carried out in th framework of the scientific program No AAAA-A17-117012610055-3 of the Central Siberian Botanical Garden SB RAS.

\section{LITERATURE CITED}

Agapova, N.D., K.B. Arkharova, L.I. Vakhtina, L.I. Zemskova \& L.V. Tarvis 1990. Chromosome numbers in flowering plants of the flora of the USSR: Aceraceae-Menyanthaceae. Nauka, St.-Petersburg, 510 pp. (in Russian). [Агапова Н.А., Архарова К.Б., Вахтина А.И., Земскова Е.А., Тарвис А.В. 1990. Числа хромосом цветковых растений флоры СССР: семейства Aceraceae-Menyanthaceae. СПб: Наука. 510 с.].

Astanova, S.B. 1989. Chromosome numbers of representatives of the family Compositae in the Tadzhikistan flora. In: The 2nd Conference on plant karyology. Proceed., pp. 89-91, Novosibirsk (in Russian). [Астанова С.Б. 1989. Хромосомные числа представителей семейства сложноцветных флоры Таджикистана // II Совещание по кариологии растений. Тез. Аокл. Новосибирск. 1989. C. 89-91].

Baumberg, H. 1970. Chromosomenzahlbestimmungen und Karyotypanalysen bei den Gattungen Anemone, Hepatica und Pulsatilla. Berichte der Schweizerischen Botanischen Gesellschaft 80:17-96.

Budantzev, A.L. 1986. Chromosome numbers and some problems in the systematics of the genus Dracocephalum (Lamiaceae). Botanicheskii Zhurnal 71(9): 1211-1217 (in Russian). [Буданцев А.А. 1986. Числа хромосом и некоторые проб̆лемы систематики рода Dracocephalum (Lamiaceae) // Ботанический журнал. Т. 71, № 9. С. 1211-1217].

Chepinoga, V.V. 2014. Chromosome numbers of plant species from Baikal Siberia. Nauka, Novosibirsk, 418 pp. (in Russian). [Yeпинога В.В. Хромосомные числа растений флоры Байкальской Сибири,2014. Новосибирск: Наука. 418 с.].

Fedorov, A.A. (ed.) 1969. Chromosome numbers of flowering plants. Nauka, Leningrad, 926 pp. (in Russian). [Хромосомные числа цветковых растений / под реА. А.А. ФеАорова. А.: Наука, 1969. 926 с.].

Goldblatt, P. \& D. E. Johnson (eds). 1979+. Index to plant chromosome numbers (IPCN). Available from http://www. 
tropicos.org/NameSearch.aspx?projectid=9. Last accessed 19.02.2019.

Krasnikov, A.A. 1985. Chromosome numbers of some Asteraceae species from Siberia. Botanicheskii Zhurnal 70(12): 1702-1703 (in Russian). [Красников А.А. 1985. Числа хромосом некоторых представителей семейства Asteraceae из Сибири // Ботанический журнац. Т. 70, № 12. C. 1702-1703].

Krasnikova, S.A., A.A. Krasnikov, T.S. Rostovtzeva \& V.M. Chanminchun. 1983. Chromosome numbers of some plant species from the south of Siberia and the Far East. Botanicheskii Zhurnal 68(6):827-835 (in Russian). [Красникова С.А., Красников А.А., Ростовцева Т.С., Ханминчун В.М. 1983. Числа хромосом некоторых видов растений юга Сибири и Аальнего Востока // Ботанический журнал. Т. 68, № 6. С. 827-835].

Krasnoborov, I.M., I.A. Artemov (eds). 2012. Plants identification guide of the Republic of Altai. Izdatelstvo SO RAN, Novosibirsk, 710 pp. (in Russian). [Определитель растений Республики А^тай / отв. реА. И.М. Красноборов, И.А. Артемов. 2012. Новосибирск: Издательство СО PAH. 701 c.].

Krasnoborov, I.M., T.S. Rostovtseva \& S.A. Ligus. 1980. Chromosome numbers of some plant species of South Siberia and the Far East. Botanicheskii Zhurnal 65(5):659668 (in Russian). [Красноборов И.М., Ростовцева Т.С., Аигус C.А. 1980. Числа хромосом некоторых вилов растений юга Сибири и Аальнего Востока // Ботанический журнал. Т. 65, № 5. С. 659-668].

Krogulevich, R.E. 1978. Karyological analysis of the flora of the East Sayan Mts. In: Flora of the Cisbaikalia (L.I. Malyschev \& G.A. Peschkova, eds.), pp. 19-48, Nauka, Novosibirsk (in Russian). [Крогулевич P.Е. Кариологический анализ вилов фморы Восточного Саяна / Прибайкалья / под реА. А.И. Малышева и Г.А. Пешковой. Новосибирск: Наука, 1978. С. 19-48].

Krogulevich, R.E. \& T.S. Rostovtseva 1984. Chromosome numbers of flower plants in Siberia and the Far East. Nauka, Novosibirsk, 286 pp. (in Russian). ГКрогулевич P.Е., Ростовцева Т.С. 1984. Хромосомные числа цветковых растений Сибири и Аальнего Востока. Новосибирск: Наука. 286 с.].

Kurbatski, V.I. 1996. Family Valerianaceae. In: Flora of Siberia, vol. 12 (A.V. Polozhii \& G.A. Peshkova, eds.), pp. 134-142, Nauka, Novosibirsk (in Russian). [Курбатский В.И. 1996. Семейство Valerianaceae / / ФАора Сибири, т. 12 / под реА. А.В. Положий и Г.А. Пешковой. Новосибирск: Наука. С. 134-142].

Peshkova, G.A. 1997. The genus Dracocephalum L. In: Flora of Siberia, vol. 11 (L.I. Malyschev, ed.), pp. 170-185, Nauka, Novosibirsk (in Russian). [Пешкова Г.А. РоА Dracocephalum L. / / Фмора Сибири, т. 11 / под ред. А.И. Мамышева. 1994. Новосибирск: Наука. С. 170-185].

Probatova, N.S., E.G. Rudyka, A.E. Kozhevnikov \& Z.V. Kozhevnikova 2004. Chromosome numbers of some representatives of the flora of the Primorsky territory. Botanicheskii Zhurnal 89(7):1209-1217 (in Russian). [Пробатова Н.С., Рудыка Э.Г., Кожевников А.Е., Кожевникова 3.В. 2004. Числа хромосом представителей флоры Приморского края // Ботанический журнал. T. 89, № 7. C. 1209-1217].

Probatova, N.S., V.Yu. Barkalov, E.G. Rudyka 2007. Karyology of the flora of Sakhalin and the Kuril Islands. The chromosome numbers, taxonomical and phytogeographical comments. Dal'nauka, Vladivostok, 392 pp. (in Russian). [Пробатова H.C., Баркалов В.Ю., Рудыка Э.Г. 2007. Кариология флоры Сахалина и Курильских островов. Числа хромосом, таксономические и фитогеографические комментарии. ВАадивосток: Аальнаука. 392 с.].
Pulkina, S.V. 1988. Chromosome numbers in some species of the Asteraceae. Botanicheskii Zhurnal 73(4):607608 (in Russian). ППулькина С.В. 1988. Числа хромосом некоторых видов семейства Asteraceae // Ботанический журнал Т. 73, № 4. С. 607-608].

Rice, A., L. Glick, S. Abadi, M. Einhorn, N.M. Kopelman, A. Salman-Minkov, J. Mayzel, O. Chay \& I. Mayrose 2014 The Chromosome Counts Database (CCDB) - a community resource of plant chromosome numbers. New Phytologist. Available from: http://ccdb.tau.ac.il/ Last accessed 19.02.2019.

Rostovtseva, T.S. 1978. Cytomixis in Dracocephalum imberbe Bunge (Lamiaceae Lindl.). Tsitologiya i genetika 12(3):218219 (in Russian). [Ростовцева T.C. 1978. Цитомиксис у Dracocephalum imberbe Bunge (сем. Lamiaceae Lindl.) // Цитомогия и генетика. Т. 12, № 3. С. 218-219].

Rybinskaya, E.V. 1994. The genera Hesperis L. - Neuroloma Andrz. In: Flora of Siberia, vol. 7 (L.I. Malyschev \& G.A. Peshkova, eds.), pp. 94-96, Nauka, Novosibirsk (in Russian). [Рыбинская E.B. Роды Hesperis L. - Neuroloma Andrz. // ФАора Сибири, т. 7 /под реА. А.И. Малышева и Г.А. Пешковой. Новосибирск: Наука, 1994. С. 94-96].

Smirnov, Y.A. 1968. Accelerated method for studying somatic chromosomes in fruit trees. Tsitologiya 10: 1132-1134 (in Russian). [Смирнов Ю.А. 1968. Ускоренный метоА исследования соматических хромосом плодовых // Цитология. Т. 10. С. 1132-1134].

Sokolovskaya, A.P. \& O.S. Strelkova 1938. The polyploidy phenomenon in highlands of Pamir and Altai. Doklady AN SSSR 21(1-2):68-71 (in Russian). [Соколовская А.П., Стрелкова О.С. 1938. Явление полиплоилии в высокогорьях Памира и А^тая. // Аоклады АН СССР. T. 21, № 1-2. C. 68-71].

Sokolovskaya, A.P. \& O.S. Strelkova 1948. Geographical distribution of polyploids. II. The study of Altai flora. Uchyonyye zapiski Leningradskogo gosudarstvennogo pedagogicheskogo instituta im. Gertsena 66(8):195-216 (in Russian). [Соколовская А.П., Стрелкова О.С. 1948. Географическое распределение полиплоидов. ІІ. Исследование флоры Алтая // Уч. Зап. Аенингр. Гос. ПеА. Инст-та им. Герцена. Т. 66, № 8. С. 195-216].

Timokhina, S.A. 1993. The genera Anemonastrum Holub Ranunculus L. In: Flora of Siberia, vol. 6 (L.I. Malyschev \& G.A. Peshkova, eds.), pp. 140-198, Nauka, Novosibirsk (in Russian). [Тимохина C.A. Роды Anemonastrum Holub - Ranunculus L. // ФАора Сибири, т. 6 / под реА. А.И. Малышева и Г.А. Пешковой. 1994. Новосибирск: Наука. С. 140-198].

Uellner, G. 1954. Cytologische Untersuchungen an Pulsatilla. Diss. Tubingen.

Volkova, S.A. \& K.P. Ulanova. 1986. Chromosome numbers in some species of Nelumbonaceae and Ranunculaceae from the Far East of the USSR. Botanicheskii Zhurnal 71(12):1292 (in Russian). ВВоккова С.А., У Аанова К.П. 1986. Числа хромосом некоторых вилов семейств $\mathrm{Ne}$ lumbonaceае и Ranunculaceae с $\triangle$ альнего Востока СССР // Ботанический журнал. Т. 71, № 12. С. 1292].

Zhukova, P.G. 1980. Chromosome numbers of some Southern Chukotka plant species. Botanicheskii Zhurnal 65(1): 51-59 (in Russian). [Жукова П.Г. 1980. Хромосомные числа некоторых видов южной Чукотки // Ботанический журнал Т. 65, № 3. С. 51-59].

Zhukova, P.G. 1982. Chromosome numbers of some plant species of North-eastern Asia. Botanicheskii Zhurnal 67(3): 360-365 (in Russian). [Жукова П.Г. Хромосомные чисма некоторых видов Северо-Восточной Азии // Ботанический журнал Т. 67, № 3. С. 360-365].. 